\title{
Efforts to Preserve of Minangkabau Songs by Dplust Band in Padang
}

\author{
Hanafi Riska ${ }^{1, *}$ Ayu Niza Machfauzia ${ }^{2}$ \\ ${ }^{1}$ Graduate School of Art Education, Yogyakarta State University, Yogyakarta 55281, Indonesia \\ ${ }^{2}$ Faculty of Languages and Arts, Yogyakarta State University, Yogyakarta 55281, Indonesia \\ ${ }^{*}$ Corresponding author. Email: hanafiriska2103@gmail.com
}

\begin{abstract}
The purpose of this study is to find out and describe the attempts to preserve Minangkabau songs by the Dpllust band in Padang and figure out the privileges experienced by Dplust band after the group was founded. This study is classified into qualitative research. It used phenomenological approach with two types of data sources: primary and secondary. The data retrieved were analyzed using data reduction, data display, and conclusion. Technical triangulation was used to validate the data. The results show that in order to preserve Minangkabau sings, the Dplust band combined modern and traditional arts. This is a social action based on rational circumstances classified into instrumental rationality because the group has been able to determine the strategy to achieve a certain goal. Additionally, the group received benefits from both economic aspects and social aspects.
\end{abstract}

Keywords: Preservation Efforts, Macapat, Phenomenology

\section{INTRODUCTION}

The Minangkabau tradition is designed based on intellect (a combination of thoughts and feelings to weigh good and bad and this refers to alam takambang jadi guru, raso jo pareso (feelings/desires with checks/controls), in addition alua jo patuik (proper measures) from which proper behaviors are derived by considering an anticipation of shame and politeness so that people can be knowledgeable in their minds and behaviors in a civilized social life [1]. The custom of Minangkabau provides a reference or guideline for values that come from the mind in living life, thus giving birth to community actions and behavior that reflect the distinctive character of the Minangkabau people.

The legacy of the Minangkabau traditional values has been carried out from generation to generation in various ways. In Minangkabau society, one of the methods used is through performance arts or Minang art, as Amir argues [2] that customs are various common practices in a nagari or nation. This prevalence generally concerns the embodiment of community cultural arts displays, such as events of the nagari crowd (young generation of the nation), such as randai dance performances, saluang (traditional flute performances), a variety of dances, and various arts. One of the types of arts that exist in Minangkabau is Minangkabau songs which contain values and describe the real conditions that occur in Minangkabau society. These values serve as guidelines in creating actions and behaviors that reflect the character of the Minangkabau people. Barendregt [3] mentions that The Minang song provides one of the ways in which identification as Minangkabau is experienced, defined, and consumed internally. The Minangkabau sensibility was built "...by depicting landscapes that can be recognized through the use of metaphors." in regards to migration and homeland.

Minangkabau songs that identify Minangkabau culture and are consumed internally can build and depict feelings about natural beauty that are recognized through the use of metaphors related to the Minang realm and the customs or traditions of migrating. Minang songs describe longing for the Minangkabau nature and even manifest as a community effort to share moral values.

Hajizar [4] states that Minang songs depart from the reception of social values. Thus, Minang songs can be described as an intimacy or closeness to Minangkabau culture, as stated by Fraser [5] Minangkabau songs are a form of 'cultural intimacy' where the Minangkabau people can see themselves differently from other constituents.

Minangkabau songs consist of two main elements. First, musical elements that are unique to Minangkabau, such as various musical instruments that are unique to Minang, such as talempong (a small kettle gong), gandang (drum), bansi (a short flute), saluang (a bamboo flute), rabab (a bowed string instrument), and kecapi 
(lute). The rhythm and melody of Minangkabau songs have a unique nuance, namely having a Minangkabau cadence (called gariniak), as stated by Budiman [4] that Minang songs are conveyed in a thick melody with a unique "gariniak" or Minang cadence. Second, elements of the lyrics of Minang songs are formed in rhymes, as stated by Darwis (2005) that pantun (a traditional oral poetic form) has played an important role in Minangkabau art. The Minang people often express their feelings in poetry, in dialogue, and even in words.

Budiman [6] argues that the lyrics represent the following saying, "Pusako urang Minang tu, iyolah kato" which means that the heirloom of the Minangkabau people is in the form of words. These words are also described as "kato bakieh (words of satire), kato bamukasuik (words intended for specific meanings), tanyo baalamat (clear questions), manggado manghadang tampuak (things that are right on target), balaia manghadang pulau (an attempt to complete the adventure)" . Every word has a specific meaning and purpose. In addition, the lyrics of Minangkabau songs have polite and guiding wisdom values.

Apart from the peculiarities of the music and the values contained in the lyrics of the songs, the Minangkabau songs are proven to be very close to the listeners or the supporting community. This can be seen from the popularity of Minang songs which are not only in the Minangkabau region, but some of these songs have been known nationally to foreign countries and even some Minangkabau songs are legendary songs. The popularity and closeness of Minangkabau songs with the supporting community indicates that the message of values contained in Minangkabau songs is accepted and lives in the hearts of the Minangkabau people. Music and lyrics of Minangkabau songs educate listeners or supporters to always observe Minangkabau traditional values and show virtuous behavior, speak politely and use polite words, love their hometown, and have awareness of upholding their own culture.

The main values of Minangkabau customs and the values contained in the Minangkabau songs described earlier are past creations that have become cultural heritage. These values are still understood, practiced, and defended by previous communities as guidelines in conducts or behaviors that reflect the character / personality of the Minangkabau community, as well as used as a means of introducing Minangkabau customs to the community. Given the value and importance of these values, these should be steadfastly manifested by the next generation. For that reason, there is a need for conservation and cultural efforts. One of the efforts that can be made in preserving and cultivating the educational values contained in Minangkabau customs and Minangkabau songs is to modify the presentations of
Minangkabau song compositions in order to keep up with the times and then easily be accepted by the next generation.

The paradigm in Minangkabau society, especially the younger generation, assumes that Minang music that has been circulating in the Minangkabau music industry locally, nationally and internationally is classified as a monotonous art presentation or in other words, outdated. The younger generation is not interested in Minangkabau music because the musical presentations are neither up to date in regards to musical developments in modern times nor contemporary.

Through digital platforms on the internet, several young generations have composed Minangkabau songs in contemporary or new styles. However, the number is quite small compared to the major Minangkabau music labels. This phenomenon has been welcomed by the younger generation with the joy of refreshing Minangkabau music, which has been considered monotonous by most of the younger generation. One of the works received by the generation of lovers of Minangkabau songs is a song with the title "Mudiak Arau" uploaded by one of the Padang city indie bands, namely Dplust, which is proven to have reached over 1.4 million viewers on the YouTube platform.

The efforts to preserve Minangkabau songs carried out by Dplust Band in the midst of the decline in the existence of Minangkabau songs among the Minangkabau young generation today have attracted researchers to conduct further studies. In addition to knowing its conservation efforts, researchers also hope to find out more about the benefits received by Dplust Band. Thus, the formulation of the problem in this study is divided into two, namely as follows; (1) How is the preservation of Minangkabau songs performed by the Dplust Band? (2) What are the benefits received by the Dplust Band group members after uploading the song "Mudiak Arau" on YouTube. Therefore, the aim of the research is to describe the efforts to preserve Minangkabau songs by Dplust Band and find out the benefits for the Dplust Band.

\section{RESEARCH METHOD}

This research is a qualitative research with a phenomenological approach. This approach is used to interpret, study, and understand the reasons for artists or informants in choosing an action as an effort to preserve Minangkabau songs for the younger generation, the purpose of this research is to describe efforts to preserve Minangkabau songs and explain the benefits received by Dplust Band. According to Collin, phenomenology tries to understand informants about emerging phenomena where they are considered as entities that exist in the world [7]. This is in line with Christensen, Johnson, and 
Turner in Simon and Goes, who argue that the main purpose of the study of phenomenology is to explain the meaning, structure, and essence of the life experience of a person or group of people about certain phenomena [8]. In short, phenomenologists try to understand human behaviors through the eyes of research participants.

The research subject is Dplust Band. Sources of data are divided into two, namely primary data sources derived from interviews, and secondary data sources obtained from observation and documentation. The data were then analyzed using data reduction, data presentation, and conclusion drawing. In this research, the data validity test is performed using triangulation techniques, namely cross-validating the interview data and the results of observation and documentation.

\section{RESULT AND DISCUSSION}

\subsection{Efforts to Preserve Minangkabau Songs}

Minangkabau songs have dominated the Minang music industry and Minang pop music is a music genre that is very popular within the Minang music market in Indonesia, both overseas and in the Minangkabau community itself. Minang songs that have been produced in the Minangkabau community have been distributed in the form of Compact Disk (CD / DVD), but since the proliferation of digital media on the internet has increasingly dominated, distribution in the form of $\mathrm{CD} /$ DVD has begun to be abandoned by previous listeners. CD / DVD of Minang songs were originally sold at a price of 15,000 to 25,000 rupiahs in the market, but since the growing number of digital media, listeners of Minangkabau songs easily get them for free. This phenomenon has made the CD / DVD of Minangkabau songs increasingly threatened by the music industry, although nationally the CD / DVD forms had been abandoned for a few years. Production in conventional form is not without reason, because consumers of Minang songs are mostly people in the regions and overseas. With the advancement of technology and the internet, the market behavior for the Minangkabau music has also shifted.

In addition to the data revealed by various players in the Minangkabau music industry, including the labels which oversee the sustainability of this industry, it also applies to Minangkabau musicians. The target consumers of Minangkabau songs, who are mostly local people and Minangkabau migrants who are scattered domestically and abroad. Industry-wise, this cannot be denied, but the Minangkabau young generation has a different reason, their disinterest in Minangkabau songs roots from a form of music that is considered monotonous or has not changed from year to year. This is not what the
Minangkabau generation have wished for the renewal of Minangkabau music in the changing times.

There have been several attempts to renew Minangkabau songs by the younger generation in line with the widespread phenomenon of cover songs for digital media such as YouTube, which until now the major Minangkabau music producers have not been able to present. However, of the few who have made efforts to reform, there are still few who actually perform with very thorough preparation, even though the reception of the Minangkabau younger generation is very good. One of the music groups that was viral among the Minangkabau younger generation is the Dplust band. Dplust band is an indie band from the city of Padang that has succeeded in captivating the attention of the Minangkabau generation with a work uploaded on YouTube with the title song Mudiak Arau, an old Minangkabau song composed and re-performed with different music and music videos with contemporary standards. .

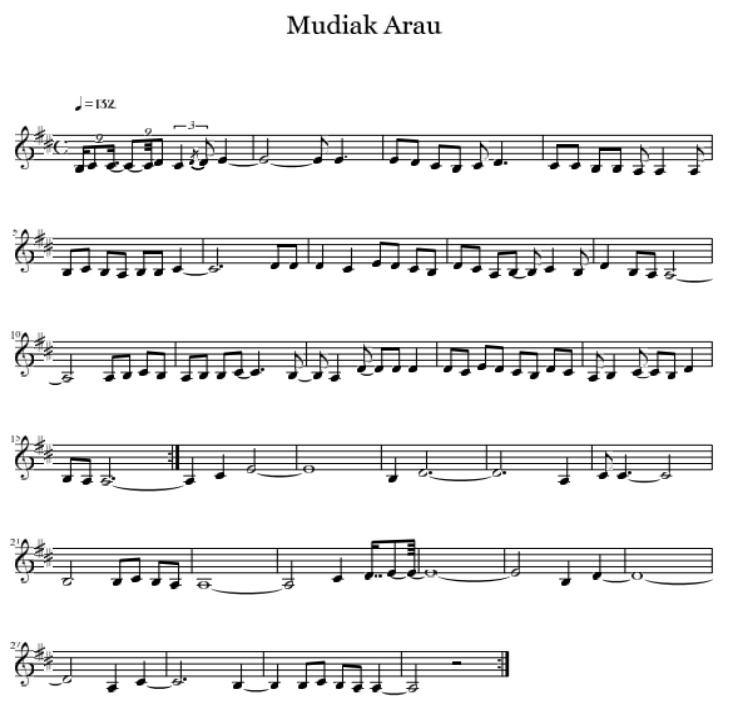

Figure 1 The Musical Notation of Mudiak Arau Song

The combination of traditional musical instruments (talempong and bansi) and modern musical instruments (guitar, bass, keyboard / synthesizer, drum set) gives a new and contemporary feel to Minangkabau songs. Packaged in a modern style without leaving out the distinctiveness of traditional Minangkabau music, it has received a good reception from Minangkabau young generation music lovers. The cover song uploaded by Dplust Musik Official on YouTube with the title Dplust - Mudiak Arau (Cover) has been watched more than 1.4 million times, with seventeen thousand likes and more than two thousand comments. The preservation effort of Minangkabau songs targeting the younger generation by the Dplust band has been successful and is still being carried out with other Minangkabau song titles, especially old Minangkabau songs. 
The success of the Dplust was involved in the cold interference of a national comic, namely Pras Teguh as a producer in the project. Pras Teguh is a former guitarist from Dplust who transformed and succeeded in the world of stand-up comedy. The main objective of the conservation efforts carried out by Dplust through a song entitled "Mudiak Arau" is to attract the interest of the younger generation to Minangkabau songs that are full of the values. Bringing back old Minangkabau songs is a new formula used by Dplust since the arrival of a new member, namely Fris Okta Falma. The traditional features presented by Fris in the work of old Minangkabau songs which are packaged in a modern style add to the attractiveness and selling power of Minangkabau songs that are considered by the younger generation to be monotonous or old school.

This effort can also be referred to as social action based on rational circumstances because there are certain goals. In achieving its goals, Dplust has succeeded in making innovations, from Minangkabau songs which are considered by the younger generation to be monotonous to being packaged with a combination of traditional and modern art. Thus, the rational actions taken by Dplust can be classified into instrumental rationality. Based on one of the theories of rational action mentioned in the introduction, according to Homans in Tuner, a person's action is the result of a calculation between the value and the likelihood of success of these actions [9], then Dplust must calculate what they do. Such calculations are more or less as follows; If Dplust creates innovations for Minangkabau songs with modern packaging without eliminating traditional elements, their success in preserving Minangkabau songs can be accepted by the younger generation, and also their success in increasing the sales of the artistic Minangkabau music records is likely to be greater. Dplust also tries to change traditional arts that were previously considered less attractive by the younger generation so that they are able to increase the selling power of the band as evidenced by the number of invitations to fill various events both inside and outside the city of Padang.

\subsection{Benefits of Preserving Minangkabau Music}

The efforts to preserve Minangkabau songs by Dplust Band have brought several benefits to its members. One of the observed benefits can be seen from an economic aspect. Dplust has earned additional revenue for its members for every show after the music video uploaded on YouTube has been well received among the younger generation. Apart from a financial perspective, other benefits come from social aspects where one of the MPA members is often involved in various cultural events and other activities related to preserving traditions such as seminars on cultural preservation. The benefit can be seen from this social aspect has enabled more recognition in the Minangkabau music industry and raised its name to become one of the popular band groups in the city of Padang. This advantage also gave him a lot of responsibility in the mission of preserving Minangkabau songs.

\section{CONClusion}

Based on the findings discussed above, it can be concluded that in the effort to preserve Minangkabau songs, one of the methods used by Dplust is to combine traditional and modern arts. Modern art that is discussed includes the use of musical instruments and others that are more up-to-date. The effort to preserve the Minangkabau songs done by Dplust is a social action based on rational states which also include specific objectives. This rational action is classified as an instrumental act of rationality because Dplust can already determine how to achieve that goal. Some of the benefits of conservation efforts felt by group members are divided into two aspects, namely economic and social. From a financial aspect, it can be seen that the Minangkabau music composed by Dplust has become a source of additional income for group members even though they carry out a mission of cultural preservation. As for the social aspect, apart from being seen from the popularity of Dplust among Padang city artists, it is clear from several offers received by one of the group members who is actively involved in various cultural events.

\section{REFERENCES}

[1] Zainuddin, M. Pelestarian dan Eksistensi Dinamis Adat Minangkabau [Preservation and Dynamic Existence of Minangkabau Customs]. Yogyakarta: Ombak, 2010.

[2] M.S., Amir. Adat Minangkabau: Pola hidup dan Tujuan Hidup Orang Minang [Minangkabau Custom: The life and Goals of the Minang People]. Jakarta: Citra Harta Prima, 2011.

[3] Barendregt, Bart. The sound of 'longing for home'. Redefining a sense of community through Minang popular music. Bijdragen tot de taal-, land-en volkenkunde/Journal of the Humanities and Social Sciences of Southeast Asia 158(3), 2002. pp. 411450. DOI: doi.org/10.1163/22134379-90003771

[4] Hajizar. Lagu padang dulu dan kini [Padang song then and now]. Retrieved March 3, 2014. URL: http://albiouna.com/umum/lagupadang-dulu-dankini 
[5] Fraser, Jennifer. Pop song as custom: Weddings, ethnicity, and entrepreneurs in West Sumatra. Ethnomusicology 55(2), 2011. pp. 200228.

DOI:

doi.org/10.5406/ethnomusicology.55.2.0200

[6] Lagu Minang Baru Muncul di Era 70-an [New Minang Songs Appeared in the 70s]. Published on 2011, March 6. Harian Haluan Padang.

[7] Collin, Finn. Social reality. Psychology Press, 1997.

[8] Simon, Marilyn K. and Jim Goes, What Is Phenomenological Research. Unpublished. URL: http://dissertationrecipes.com/wpcontent/uploads/2 011/04/PhenomenologicalResearch.pdf

[9] Kinseng, Rilus A. Structugency: A Theory of Action. Sodality: Jurnal Sosiologi Pedesaan 5(2), 2017. DOI: doi.org/10.22500/sodality.v5i2.17972 